\section{International Scientific Journal Theoretical \& Applied Science}

p-ISSN: 2308-4944 (print)

e-ISSN: 2409-0085 (online)

Year: 2017

Issue: 02

Volume: 46

Published: $28.02 .2017 \quad$ http://T-Science.org
Denis Chemezov

Master of Engineering and Technology, Corresponding

Member of International Academy of Theoretical and Applied Sciences, Lecturer of Vladimir Industrial College, Russian Federation chemezov-da@yandex.ru

SECTION 7. Mechanics and machine construction.

\title{
DESIGNING AND MANUFACTURING OF THE TOOL OF THE SECOND ORDER
}

Abstract: The article is presented the technology of manufacture of the tool electrode to machining the mold cavity with using the computer aided design Pro/ENGINEER.

Key words: a tool electrode, machining, a cutting tool, a CNC machine, a workpiece, a coordinate axis.

Language: English

Citation: Chemezov D (2017) DESIGNING AND MANUFACTURING OF THE TOOL OF THE SECOND ORDER. ISJ Theoretical \& Applied Science, 02 (46): 163-172.

Soi: http://s-o-i.org/1.1/TAS-02-46-28 Doi: crossef https://dx.doi.org/10.15863/TAS.2017.02.46.28

\section{Introduction}

The tool of the second order is the tool for manufacturing of the other tool.

The complex and accuracy surfaces of the technological tooling, such as injection mold [1], it is advisable to perform by the special tool for the physical-technical processing. On the working part of the tool electrode [2] it is performed a contoured surface identical by the contour of the machined surface of the workpiece. In dependence on the material of the workpiece the tool electrode can be manufactured from the graphite carbon, the copper, the aluminum alloys, the cast iron, the brass, and also extruded alloy of the copper and the tungsten. The tools electrodes are manufactured on the milling machines or in the case of machining of the hard alloy on the electrical discharge machines.

The stages of designing and subsequent manufacturing of the tools electrodes of the complex configuration are implemented with using of the modern computer-aided design of the technological processes by machining and the automated technological equipment.

Let us consider the each stage in more detail. The drawing which offered to manufacturing of the tool electrode is presented in Fig. 1.

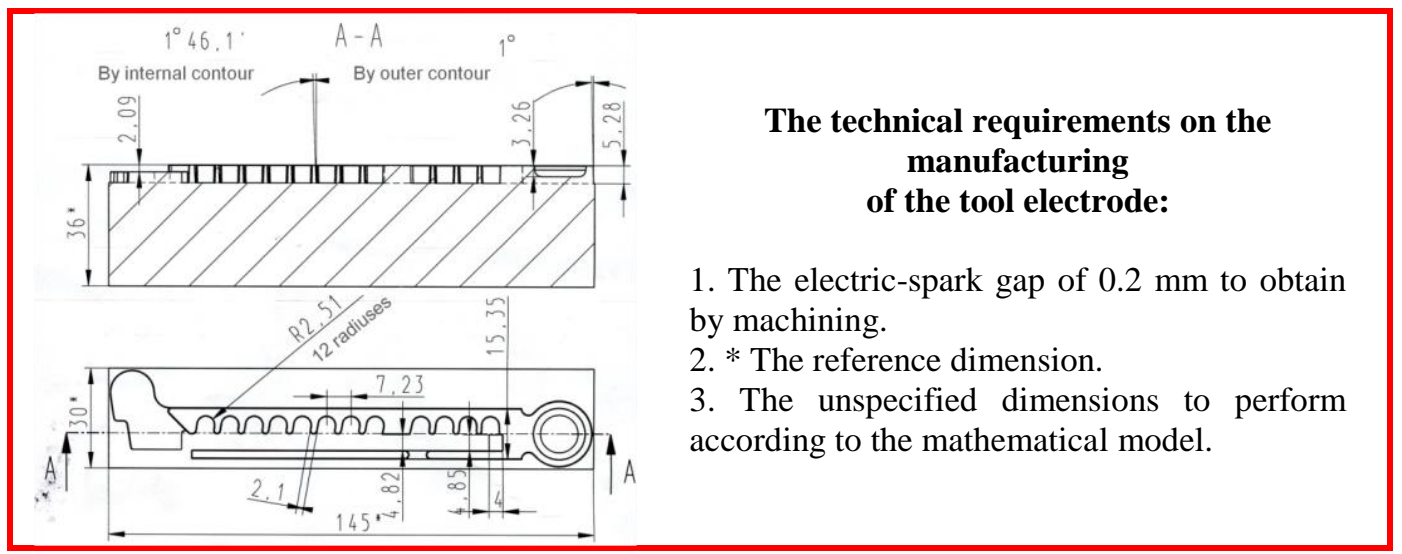

Figure 1 - The drawing of the tool electrode.

As material of the workpiece for the manufacturing of the tool electrode it was used the copper mark M1 (GOST 5638-75) [3].

\section{Designing of the tool}

The movable die half is part of the mold for the injection molding of the range of parts. 3D solid model of the part is presented in Fig. 2. 


\begin{tabular}{l|lrl|l|ll} 
& ISRA (India) & $=\mathbf{1 . 3 4 4}$ & SIS (USA) & $=\mathbf{0 . 9 1 2}$ & ICV (Poland) & $=\mathbf{6 . 6 3 0}$ \\
Impact Factor: & ISI (Dubai, UAE) $=\mathbf{0 . 8 2 9}$ & PUHL (Russia) $=\mathbf{0 . 2 3 4}$ & PIF (India) & $=\mathbf{1 . 9 4 0}$ \\
& GIF (Australia) & $\mathbf{0 . 5 6 4}$ & ESJI (KZ) & $=\mathbf{1 . 0 4 2}$ & IBI (India) & $=\mathbf{4 . 2 6 0}$ \\
& JIF & $\mathbf{1 . 5 0 0}$ & SJIF (Morocco) & $=\mathbf{2 . 0 3 1}$ & & \\
\hline
\end{tabular}

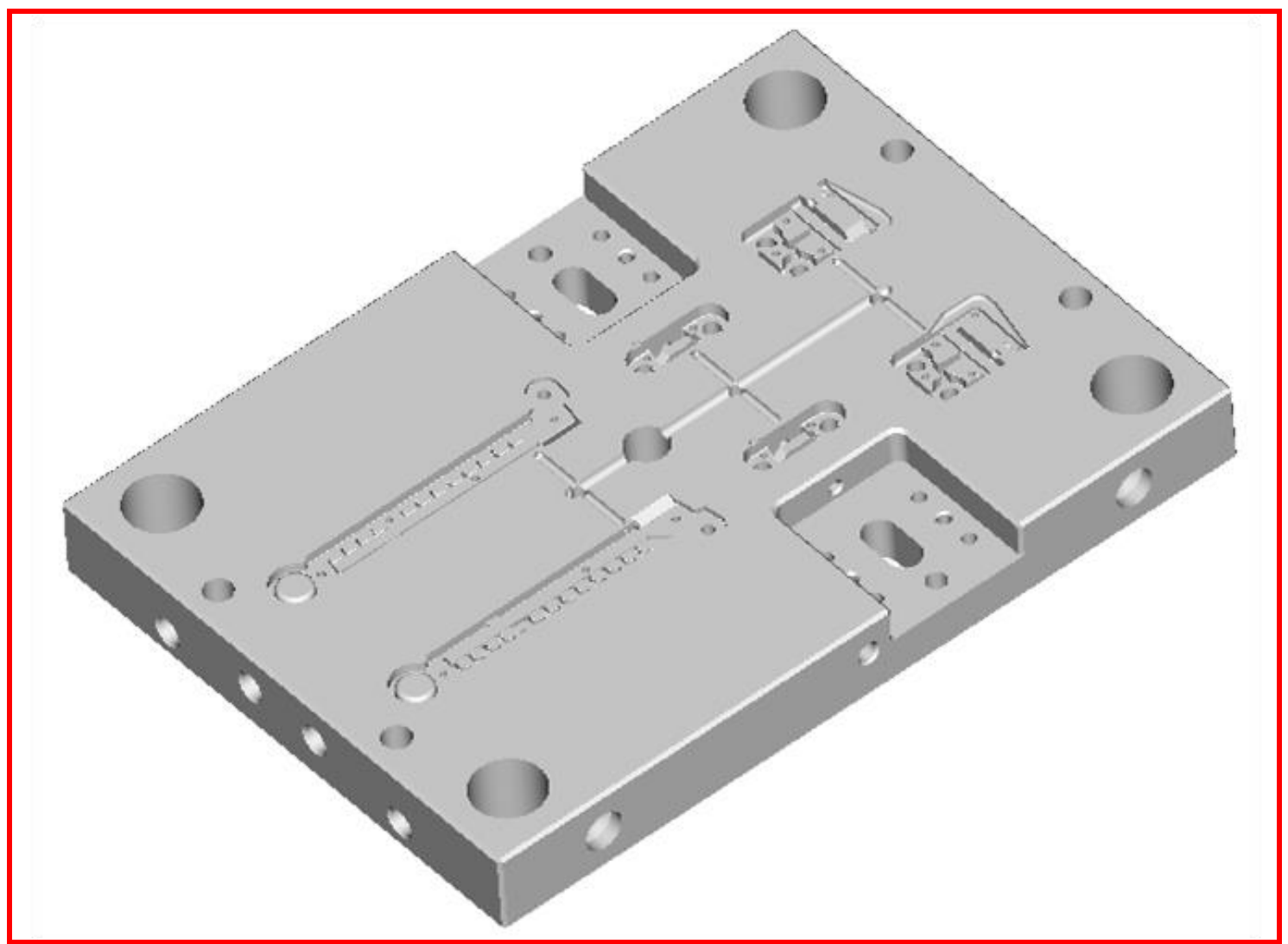

Figure 2 - Three-dimensional model of the part mold "Movable die half".

On the working surface die half it is required to manufacture one of the cavities for casting of the part "Comb". The configuration of the cavity is presented in Fig. 3. Due to the high technical requirements to machining accuracy, part geometry and the physicalmechanical properties of the material, machining of the workpiece it is advisable to perform on the machine with the computer numerical control (CNC). Straight angles in the grooves and the narrow grooves with a width of about $1 \mathrm{~mm}$ were detected when the detailed examination of the machined surfaces, to perform which is not possible on a CNC milling machine, as in them will remain the radius from the cutting tool. In such situations it is performed electrical discharge machining, which consists in the changing of the form, the dimensions, roughness and the properties of surface of the conductive workpiece under the action of electrical discharges occurring between the workpiece and the tool electrode [4].

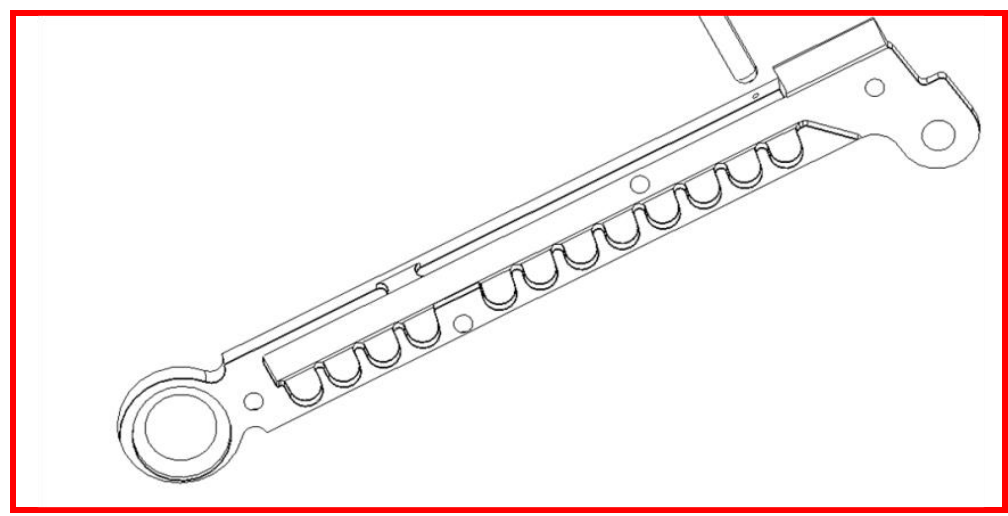

Figure 3 - The configuration of the mold cavity for casting of the part "Comb".

The tool of the second order was designed in the software product Pro/ENGINEER [5] in the section "Manufacturing Mold Cavity" (Fig. 4). In this section we can design the three-dimensional model of the electrode by filling a solid body the necessary surfaces in the machined cavity of the movable die half. 


\begin{tabular}{l|lrl|l|ll} 
& ISRA (India) & $=\mathbf{1 . 3 4 4}$ & SIS (USA) & $=\mathbf{0 . 9 1 2}$ & ICV (Poland) & $=\mathbf{6 . 6 3 0}$ \\
Impact Factor: & ISI (Dubai, UAE) $=\mathbf{0 . 8 2 9}$ & PUHU (Russia) $=\mathbf{0 . 2 3 4}$ & PIF (India) & $=\mathbf{1 . 9 4 0}$ \\
& GIF (Australia) & $\mathbf{0 . 5 6 4}$ & ESJI (KZ) & $=\mathbf{1 . 0 4 2}$ & IBI (India) & $\mathbf{4 . 2 6 0}$
\end{tabular}

\begin{tabular}{|c|c|}
\hline E New & $x$ \\
\hline 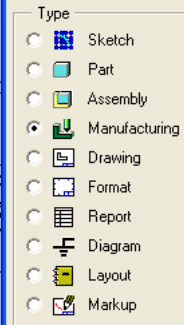 & 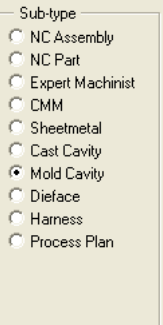 \\
\hline \multicolumn{2}{|l|}{ Name } \\
\hline OK & Cancel \\
\hline
\end{tabular}

Figure 4 - The choice of the section "Manufacturing Mold Cavity" in the software environment Pro/ENGINEER to the creation of the model of the electrode.

First need to draw the contour of the cavity to the overall dimensions, indicated on the working drawing part of the mold. After this need to fill the cavity by solid body, the working departure to extend and the parts cut off which don't require of the electrical discharge machining. In the created three- dimensional solid model of the tool electrode has remained one difficult-to-cut place that is designed in the section for machining electric discharge cutting at last. The stages of the creation 3D model of the tool electrode are presented in Fig. 5.

a)

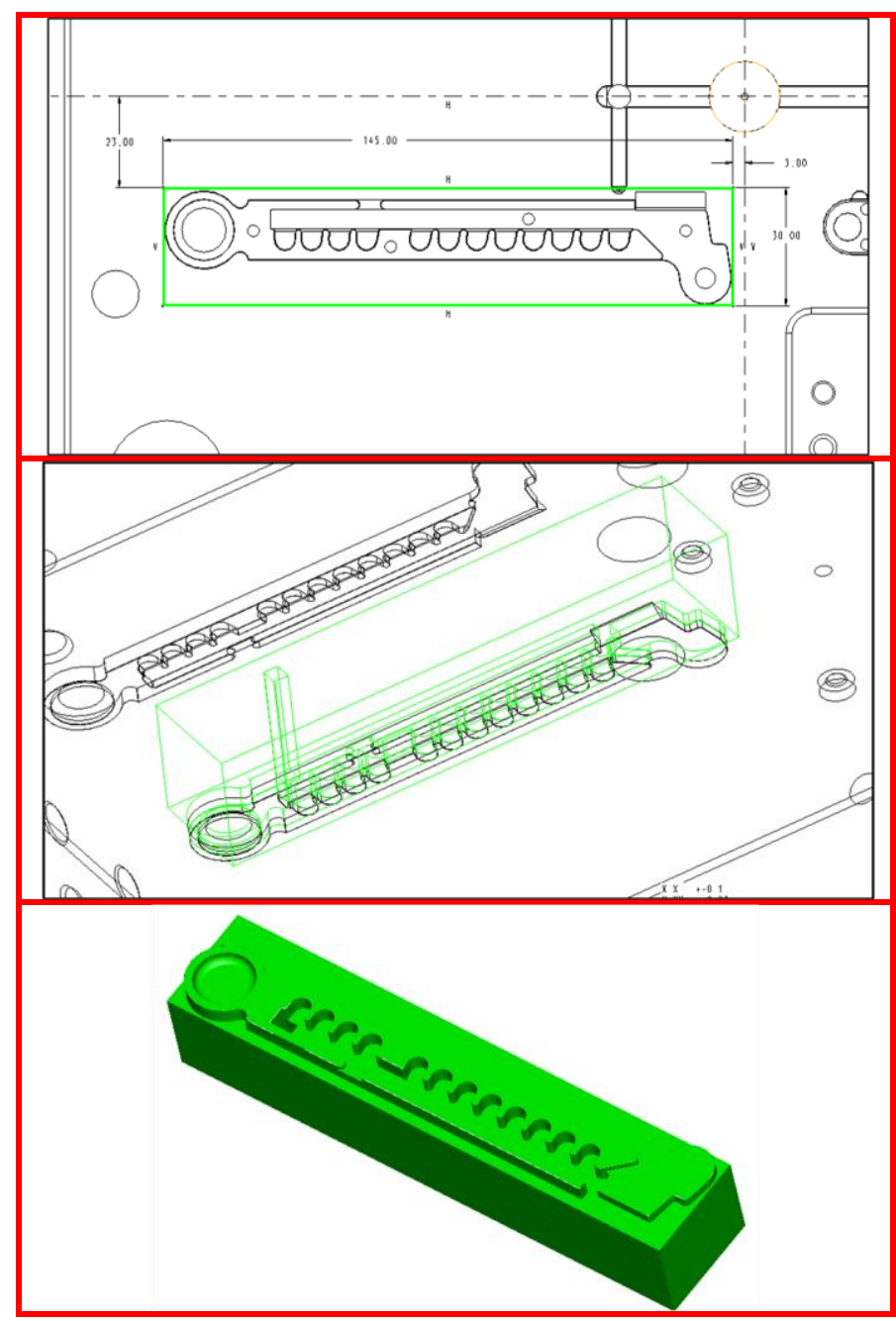

Figure 5 - The creation of the three-dimensional model of the tool electrode: a - a drawing of contour of the electrode; $b$ - a filling of the solid body of surfaces of the cavity; $c$ - a general view of the three-dimensional solid model of the electrode. 


\begin{tabular}{|c|c|c|c|c|c|c|}
\hline Impact Factor: & $\begin{array}{l}\text { ISRA (India) } \\
\text { ISI (Dubai, UAE } \\
\text { GIF (Australia) } \\
\text { JIF }\end{array}$ & $\begin{array}{l}=1.344 \\
=0.829 \\
=0.564 \\
=1.500\end{array}$ & $\begin{array}{l}\text { SIS (USA) } \\
\text { PИНЦ (Russia) } \\
\text { ESJI (KZ) } \\
\text { SJIF (Morocco) }\end{array}$ & $\begin{array}{l}=0.912 \\
=0.234 \\
=1.042 \\
=2.031\end{array}$ & $\begin{array}{l}\text { ICV (Poland) } \\
\text { PIF (India) } \\
\text { IBI (India) }\end{array}$ & $\begin{array}{l}=6.630 \\
=1.940 \\
=4.260\end{array}$ \\
\hline
\end{tabular}

\section{the tool}

The simulation of the machining process of

In the section "NC Manufacturing Part" was performed the simulation of the machining process of the tool electrode, the technological machining steps and the compilation of the numerical control (NC) program for the $\mathrm{CNC}$ milling machine.

One of the stages of simulation is the assignment of a reference point of coordinate system of the machine and the dimensions of the workpiece. In this case the dimensions of the workpiece will be equal to the overall dimensions of the model of the electrode. The compliance of the dimensions is provided by grinding of the workpiece with six sides (the dimensions on the working drawing).

The reference point of coordinate system of the $\mathrm{CNC}$ milling machine [6] is assigned. This point will be zero machining. $\mathrm{X}$ and $\mathrm{Y}$ coordinates are assigned in the geometric center of the workpiece, $\mathrm{Z}$ - on the top surface of the workpiece.

Machining of the tool electrode is comprised from six machining steps:

1. Pre-machining by the end mill.

2. Finish machining by the end mill.
3. Machining of the base planes for binding on the CNC electric discharge machine.

4. Finish machining of the unmachined places by the end mill.

5. Finish machining of the pocket with a fillet by the spherical milling cutter.

6. Drilling of the hole for entry of wire with a diameter of $2.5 \mathrm{~mm}$.

The each cutting tool is given a serial number in the tool selection chart.

The end mill with a diameter of $8 \mathrm{~mm}$ and a length of $100 \mathrm{~mm}$ was selected to perform preliminary removal of volume of the material with allowance on the further finish machining. The machining options: the movements of the cutting tools, the cutting parameters, the settings of the machine spindle, supply and withdrawal of the tools were set. The following parameters of feed of the cutting tool were set for the first machining step: cut feed $-700 \mathrm{~mm} / \mathrm{min}$, free feed $-4000 \mathrm{~mm} / \mathrm{min}$, retract feed $-4000 \mathrm{~mm} / \mathrm{min}$, plunge feed -50 $\mathrm{mm} / \mathrm{min}$, arc feed control - tool center.

The simulation of pre-machining of the workpiece is presented in Fig. 6 .

a)

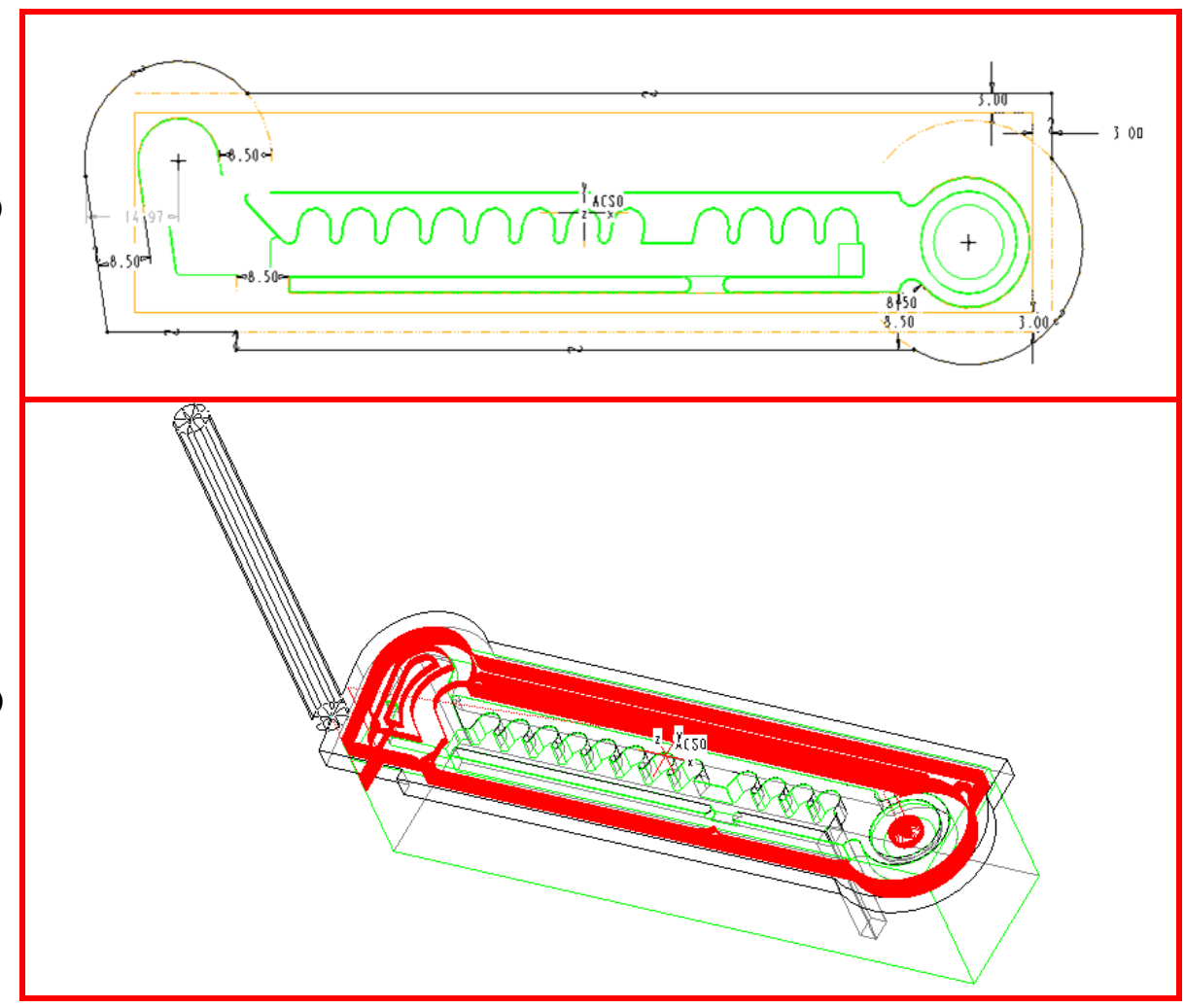

Figure 6 - The simulation of pre-machining of the workpiece: a - the setting of the amount of removed material; $b$ - the trajectory of the cutting tool for the first machining step.

The volume of the material given of diameter of the cutting tool and the existing allowances was set. The program in the automatically mode calculates the optimal trajectory of the cutting tool in a specified volume.

To perform of finish machining it was selected the end mill with a diameter of $4 \mathrm{~mm}$ and a length of 


\begin{tabular}{|c|c|c|c|c|c|c|}
\hline Impact Factor: & $\begin{array}{l}\text { ISRA (India) } \\
\text { ISI (Dubai, UAE } \\
\text { GIF (Australia) } \\
\text { JIF }\end{array}$ & $\begin{array}{l}=1.344 \\
=0.829 \\
=0.564 \\
=1.500\end{array}$ & $\begin{array}{l}\text { SIS (USA) } \\
\text { PИНЦ (Russia) } \\
\text { ESJI (KZ) } \\
\text { SJIF (Morocco) }\end{array}$ & $\begin{array}{l}=0.912 \\
=0.234 \\
=1.042 \\
=2.031\end{array}$ & $\begin{array}{l}\text { ICV (Poland) } \\
\text { PIF (India) } \\
\text { IBI (India) }\end{array}$ & $\begin{array}{l}=6.630 \\
=1.940 \\
=4.260\end{array}$ \\
\hline
\end{tabular}

$100 \mathrm{~mm}$. The simulation of finish machining of the

workpiece is presented in Fig. 7.

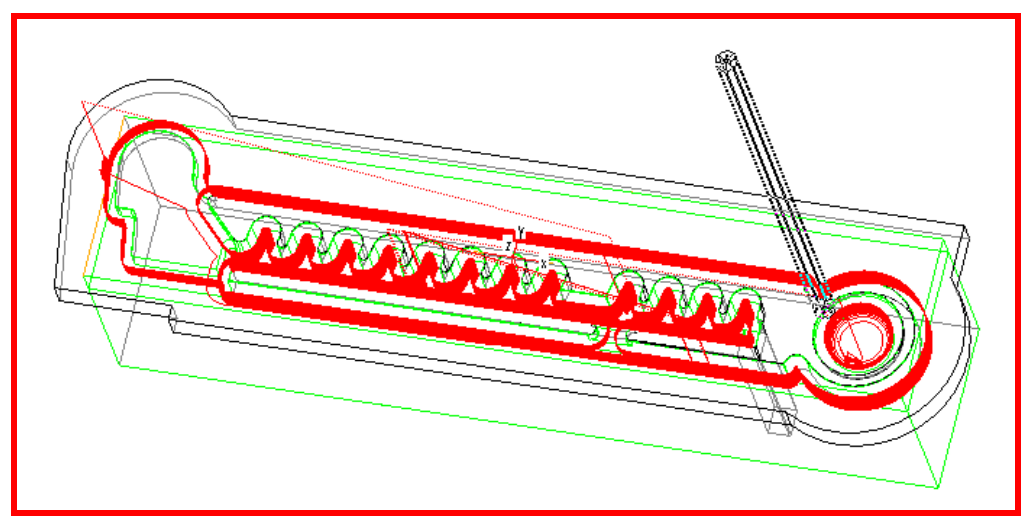

Figure 7 - The trajectory of the cutting tool for finish machining of the workpiece.

The volume of milling from pre-machining with the movement of the cutting tool only on profile of the part was used.
To perform of machining of the base planes it is used the cutting tool from the previous machining step. The simulation of machining of the base planes of the workpiece is presented in Fig. 8.

a)

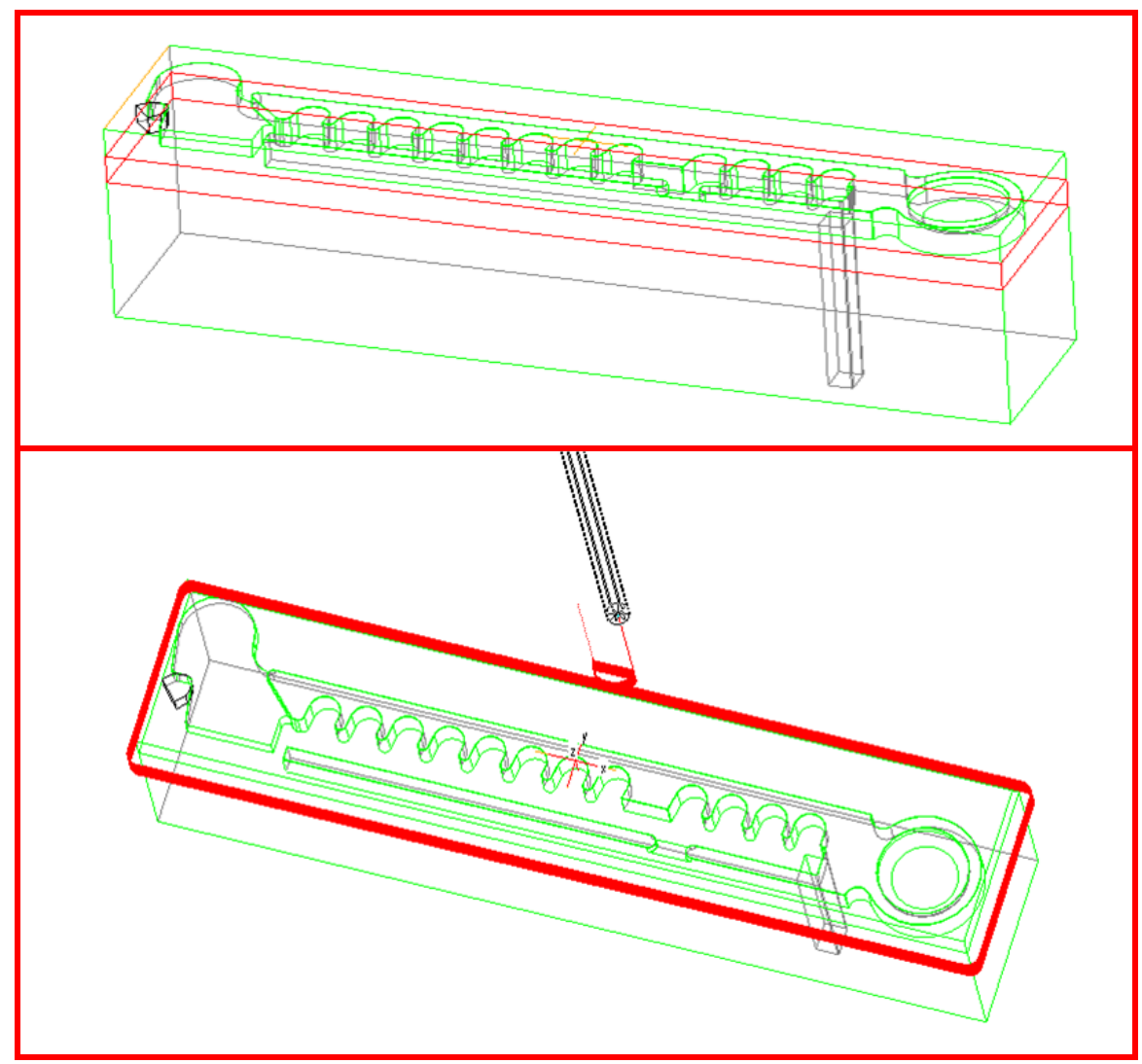

Figure 8 - The simulation of machining of the base surfaces: $a$ - a choice of profile of the model; $b$ - the trajectory of the cutting tool for the third machining step.

The profile of the model of the electrode by depth of $5 \mathrm{~mm}$ is selected. The program calculates the line-by-line movement of the end mill on the profile with the smooth entry and outlet of the cutting tool by the radius.

After the finish machining step of the end mill with a diameter of $4 \mathrm{~mm}$ remains allowance in places where the inner radius less than $2 \mathrm{~mm}$. In this case a separated machining step is created. To perform of machining of the unmachined places of the workpiece (machining of smaller radiuses and narrow grooves) was selected the end mill with a diameter of $2 \mathrm{~mm}$ and a length of $100 \mathrm{~mm}$. The 


\begin{tabular}{|c|c|c|c|c|c|c|}
\hline Impact Factor: & $\begin{array}{l}\text { ISRA (India) } \\
\text { ISI (Dubai, UAE } \\
\text { GIF (Australia) } \\
\text { JIF }\end{array}$ & $\begin{array}{l}=1.344 \\
=0.829 \\
=0.564 \\
=1.500\end{array}$ & $\begin{array}{l}\text { SIS (USA) } \\
\text { PИНЦ (Russia) } \\
\text { ESJI (KZ) } \\
\text { SJIF (Morocco) }\end{array}$ & $\begin{array}{l}=0.912 \\
=0.234 \\
=1.042 \\
=2.031\end{array}$ & $\begin{array}{l}\text { ICV (Poland) } \\
\text { PIF (India) } \\
\text { IBI (India) }\end{array}$ & $\begin{array}{l}=6.630 \\
=1.940 \\
=4.260\end{array}$ \\
\hline
\end{tabular}

simulation of machining of the unmachined places of the workpiece is presented in Fig. 9.

Volumes were created in the unmachined surfaces of the workpiece. The program calculates the optimal trajectory of the cutting tool with the ramping at an angle.

a)

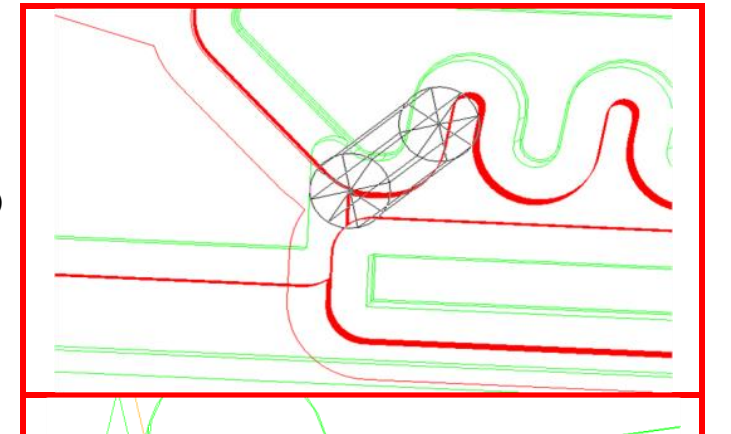

b)

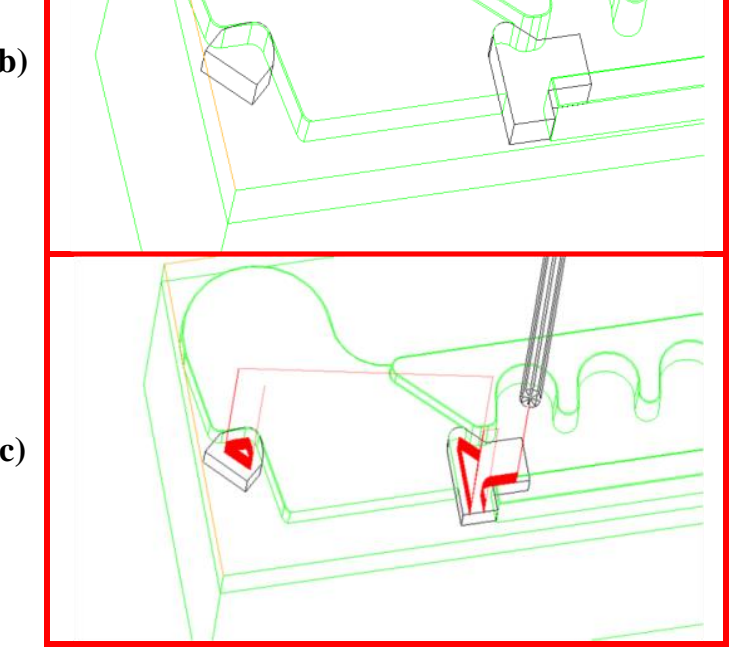

Figure 9 - The simulation of machining of the unmachined surfaces of the workpiece: a - allocation of the allowance for designing of a separate machining step; $b$ - the creation of volumes in the unmachined surfaces; $\mathrm{c}$ - the trajectory of the cutting tool for the fourth machining step.

The spherical surface was machined by the spherical milling cutter with a diameter of $4 \mathrm{~mm}$, a radius of $2 \mathrm{~mm}$ and a length of $100 \mathrm{~mm}$. After selecting of the machined surface on the workpiece, the program calculates the optimal trajectory of the cutting tool with the ramping at an angle. The simulation of machining of the spherical surface is presented in Fig. 10.

Drilling of the hole was carried out by the drill with a diameter of $2.5 \mathrm{~mm}$ and a length of $100 \mathrm{~mm}$. In the center of the window where it is necessary to drill the hole, was hold the axis AA_1. For drilling it is necessary to select the axis and the depth of machining through the entire part to indicate. The simulation of drilling of the through hole is presented in Fig. 11.

The trajectory of the cutting tool with the periodic output of the chip calculates by the program.

After the calculation of all machining steps, and the ordering them in accordance with the technological process of machining of the workpiece $\mathrm{NC}$ program is generated. NC program is displayed on the CNC milling machine by model $400 \mathrm{~V}$ [7] with the machine control panel SIEMENS SINUMERIK 802D sl [8] (Sterlitamak plant). For this a shared assembly of the subprogrammes is created and the machine identifier UNCX01.P12 is selected (Fig. 12). 


\begin{tabular}{l|lrl|l|ll} 
& ISRA (India) & $=\mathbf{1 . 3 4 4}$ & SIS (USA) & $=\mathbf{0 . 9 1 2}$ & ICV (Poland) & $=\mathbf{6 . 6 3 0}$ \\
Impact Factor: & ISI (Dubai, UAE) $=\mathbf{0 . 8 2 9}$ & PUHL (Russia) $=\mathbf{0 . 2 3 4}$ & PIF (India) & $=\mathbf{1 . 9 4 0}$ \\
& GIF (Australia) & $\mathbf{0 . 5 6 4}$ & ESJI (KZ) & $=\mathbf{1 . 0 4 2}$ & IBI (India) & $=\mathbf{4 . 2 6 0}$ \\
& JIF & $\mathbf{1 . 5 0 0}$ & SJIF (Morocco) & $=\mathbf{2 . 0 3 1}$ & & \\
\hline
\end{tabular}

a)

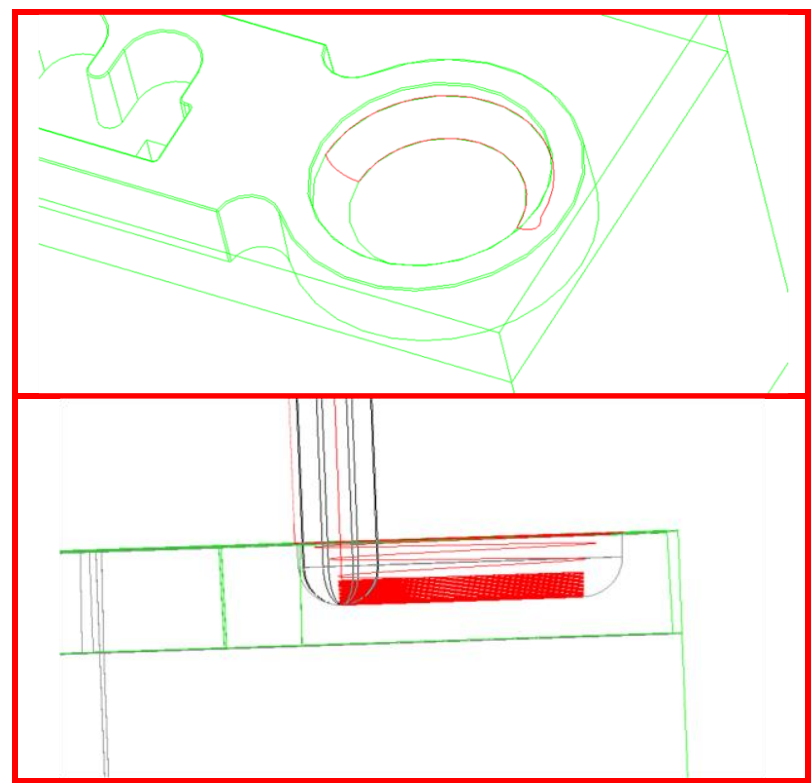

Figure 10 - The simulation of machining of a spherical surface: $a$ - a choice of the machined surface; $b$ - the trajectory of the cutting tool for the fifth machining step.

a)

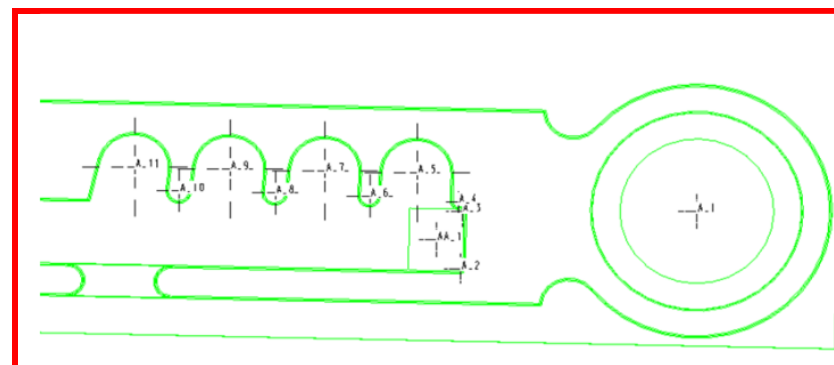

b)

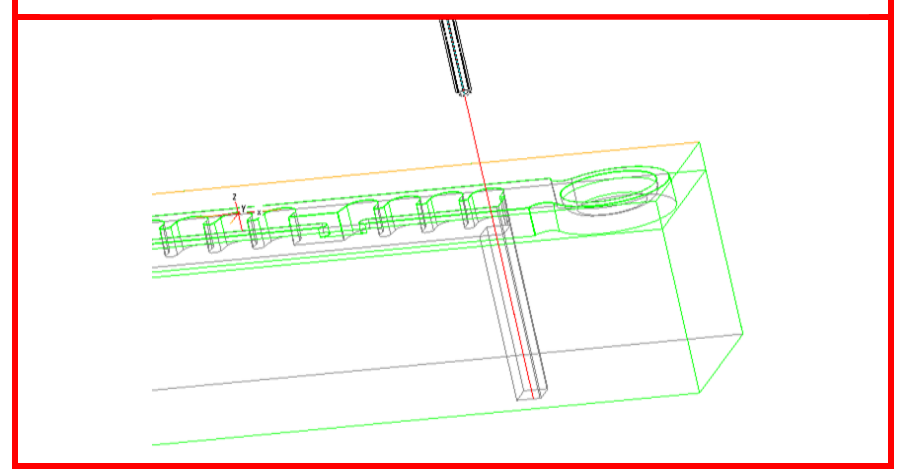

Figure 11 - The simulation of drilling hole in the workpiece: a - holding of the axis in the center of the workpiece; $b$ - a choice the axis and the depth of drilling for execution of the sixth machining step. 


\begin{tabular}{|c|c|c|c|c|c|c|}
\hline Impact Factor: & $\begin{array}{l}\text { ISRA (India) } \\
\text { ISI (Dubai, UAE } \\
\text { GIF (Australia) } \\
\text { JIF }\end{array}$ & $\begin{array}{l}=1.344 \\
=0.829 \\
=0.564 \\
=1.500\end{array}$ & $\begin{array}{l}\text { SIS (USA) } \\
\text { PИНЦ (Russia) } \\
\text { ESJI (KZ) } \\
\text { SJIF (Morocco) }\end{array}$ & $\begin{array}{l}=0.912 \\
=0.234 \\
=1.042 \\
=2.031\end{array}$ & $\begin{array}{l}\text { ICV (Poland) } \\
\text { PIF (India) } \\
\text { IBI (India) }\end{array}$ & $\begin{array}{l}=6.630 \\
=1.940 \\
=4.260\end{array}$ \\
\hline
\end{tabular}

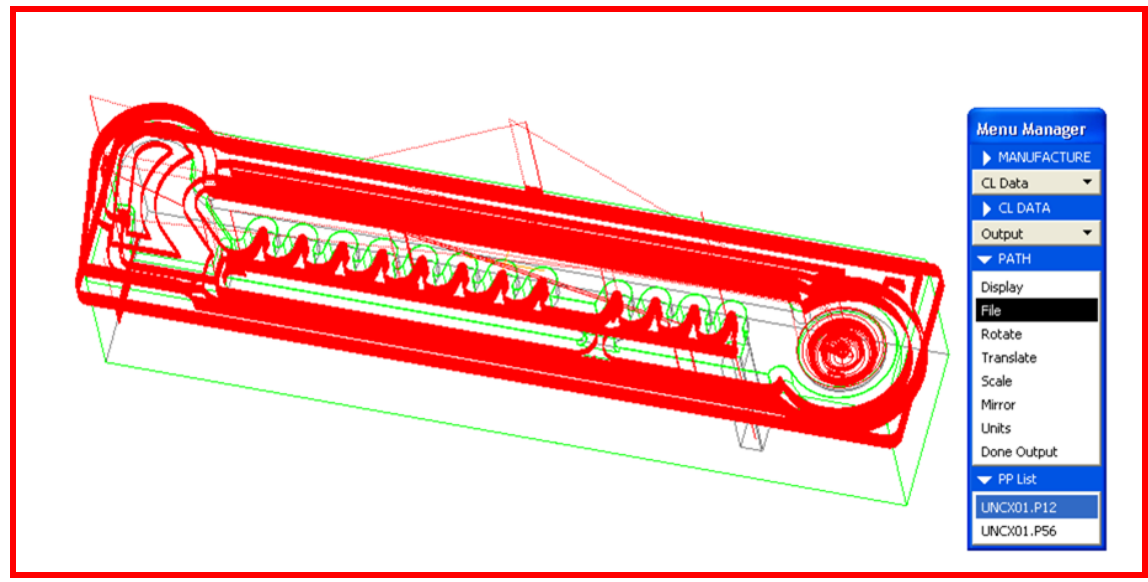

Figure 12 - The trajectories of the cutting tools for machining of the tool electrode and the selection of the machine identifier.

a)

c)

e)

g)

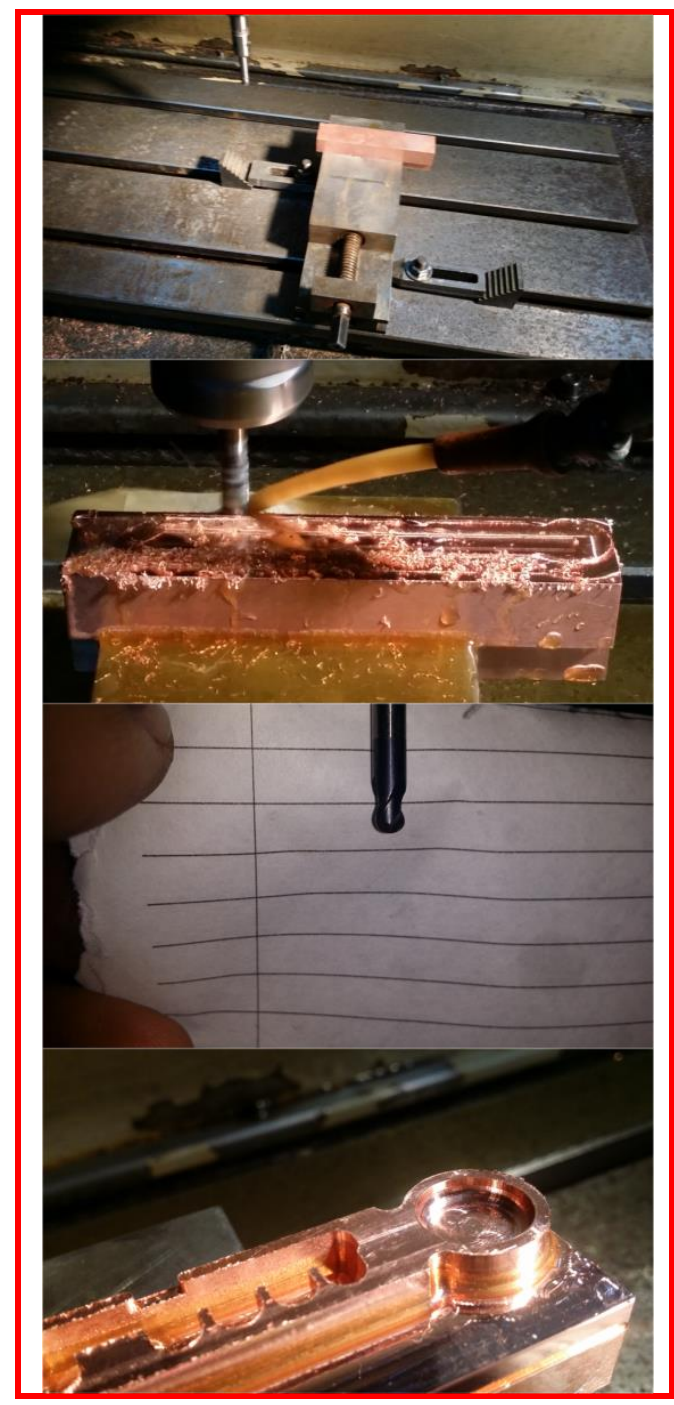

b)

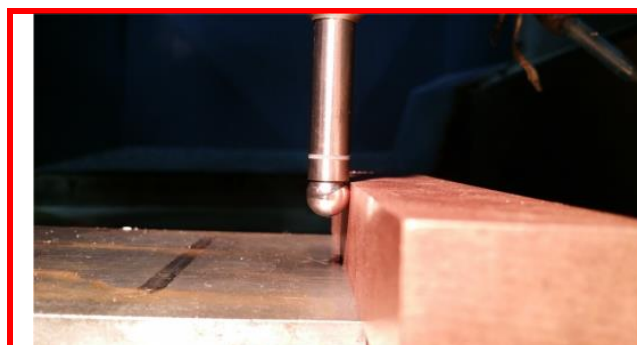

d)

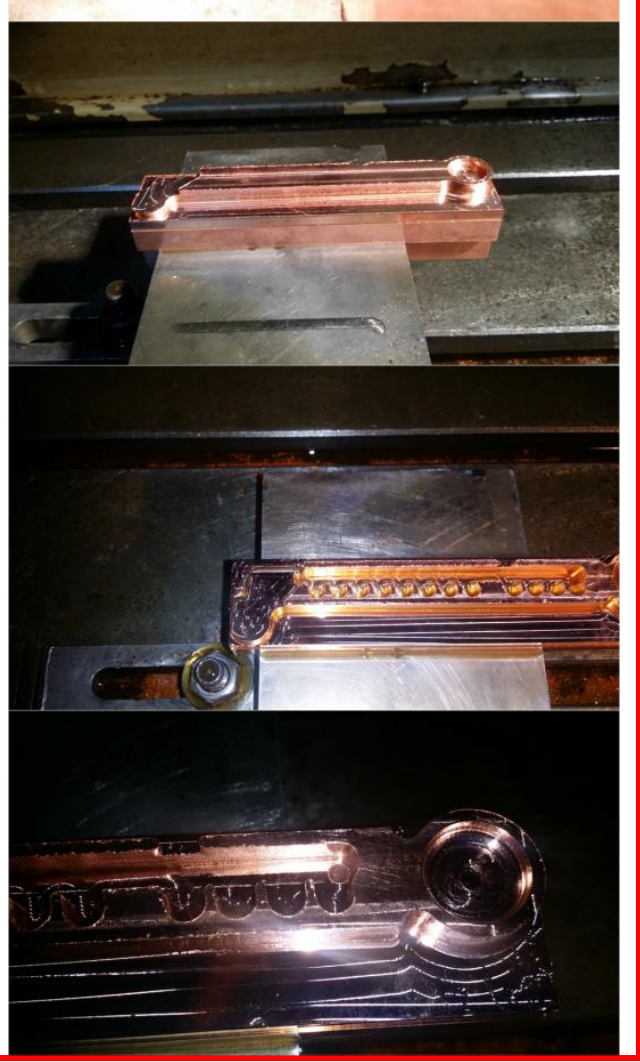

Figure 13 - Machining of the tool electrode on the $\mathrm{CNC}$ milling machine: a - a setting of the workpiece in the vise; $b$ - an orientation (binding) of the workpiece by the coordinate axes $X$ and $Y$ by using a measuring probe; $c$ - a cycle of pre-machining of the workpiece by the end mill; $d$ - machined surfaces of the workpiece after the second and the third machining steps; $\mathrm{e}-\mathrm{a}$ spherical milling cutter for execution of the fourth machining step; $\mathbf{f}$ - machined surfaces of the workpiece after the fourth machining step; $\mathbf{g}$ - machined surfaces of the workpiece after the fifth machining step; $h$ - machined surfaces of the workpiece after the sixth machining step. 


\begin{tabular}{|c|c|c|c|c|c|c|}
\hline Impact Factor: & $\begin{array}{l}\text { ISRA (India) } \\
\text { ISI (Dubai, UAE } \\
\text { GIF (Australia) } \\
\text { JIF }\end{array}$ & $\begin{array}{l}=1.344 \\
=0.829 \\
=0.564 \\
=1.500\end{array}$ & $\begin{array}{l}\text { SIS (USA) } \\
\text { PИНЦ (Russia) } \\
\text { ESJI (KZ) } \\
\text { SJIF (Morocco) }\end{array}$ & $\begin{array}{l}=0.912 \\
=0.234 \\
=1.042 \\
=2.031\end{array}$ & $\begin{array}{l}\text { ICV (Poland) } \\
\text { PIF (India) } \\
\text { IBI (India) }\end{array}$ & $\begin{array}{l}=6.630 \\
=1.940 \\
=4.260\end{array}$ \\
\hline
\end{tabular}

\section{Machining of the workpiece on the $\mathrm{CNC}$ milling machine}

The sequence of machining of the workpiece on the technological equipment is presented in Fig. 13.

According to the technological process, the fixing of the workpiece on the machine was carried out in a vice. The jaws vice on the CNC milling machine were oriented along the $\mathrm{X}$-axis. It was necessary to orient of the workpiece, thus to bind it in the coordinates of the CNC machine. The geometric center of the workpiece and its top plane are by the frame of reference in the NC program. As a tool for orientation of the workpiece by the coordinate axes $\mathrm{X}$ and $\mathrm{Y}$ it was used measuring probe with the light and the sound indicators. The orientation of the workpiece along the $\mathrm{X}$-axis was performed in the following sequence:

1. The movement of probe to the side surface of workpiece until the indication of touching.

2. Equating of coordinate of the workpiece towards zero.

3. The movement in the opposite direction of the workpiece and carrying out of the procedure of touching in accordance with items 1 and 2 .

4. The division of value of the obtained coordinate (X-axis) into two for the movement of the zero coordinate of machine in the center of the workpiece.

The process of the orientation of the workpiece on the Y-axis executes similarly.
The orientation of the workpiece on the Z-axis is performed by the binding of the cutting tools. It is necessary to set in the chucks all cutting tools and to set them in the tool bank of the CNC milling machine in accordance with the tool selection chart $(1,2,3,4$ and 5). Binding of the cutting tool is performed by means of the end measure by thickness of $3 \mathrm{~mm}$. The end measure is set between the cutting tool and the top plane of the workpiece. The movement of the cutting tool along the $\mathrm{Z}$-axis is performed before the touching its face cutting edges of the end measure. This sequence of the actions is performed for each cutting tool.

The machining cycle of the workpiece on the CNC milling machine is performed when NC program starts up of in menu of the program.

\section{Conclusion}

The control of the technological process of designing of the complex to configuration of the cutting tools and technological tooling allows to manufacture parts of high accuracy. In accordance with the presented sequence of designing stages in the software environment Pro/ENGINEER and machining of the workpiece on the CNC machine the labor intensity of the actions at observance the technical requirements on the manufacturing of finished products reduces.

The part "Comb" which was manufactured by the casting method is presented in Fig. 14.

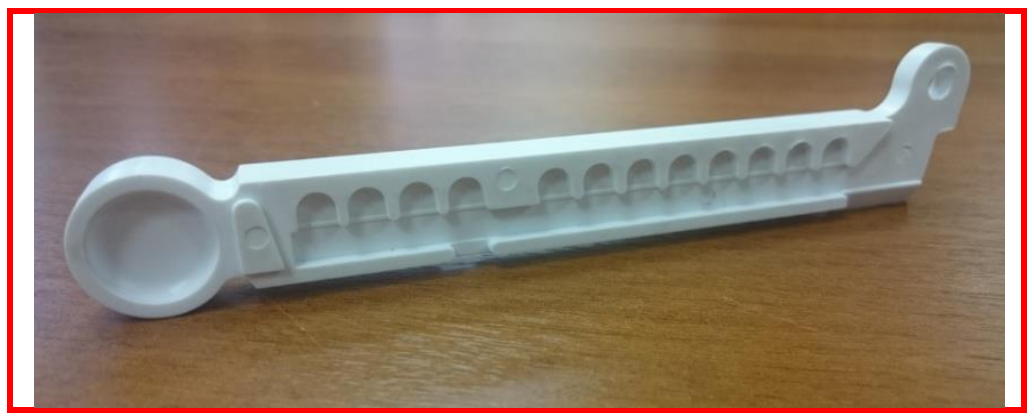

Figure 14 - The part "Comb".

\section{References:}

1. (2017) Injection moulding. Available: https://en.wikipedia.org/wiki/Injection_mouldin g (Accessed: 22.02.2017).

2. (2017) Basic information about electrical discharge machining. Available:

http://metallicheckiyportal.ru/articles/obrabotka/elektroerozionnaya/osnovnie svedenia/7 (Accessed: 22.02.2017)
3. (2017) Characteristics for grade M1. Available: http://splav-

kharkov.com/en/e_mat_start.php?name_id $=111$ I (Accessed: 22.02.2017).

4. (2017) Electrical discharge machining. Available:

https://en.wikipedia.org/wiki/Electrical_dischar ge machining (Accessed: 22.02.2017). 


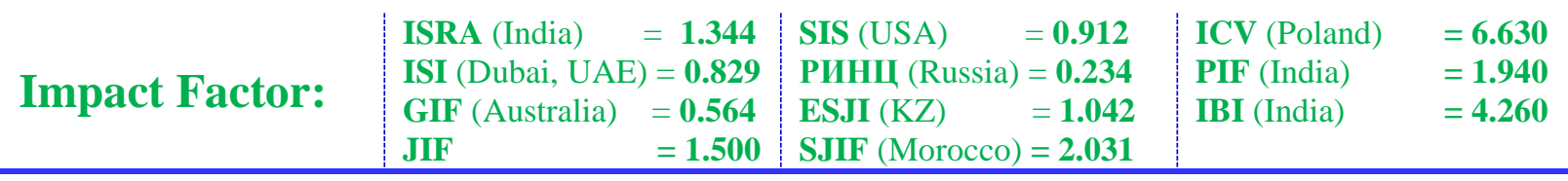

5. Aborkin AV, Elkin AI, Zhdanov AV, Ivanchenko AB (2012) Product design in the system Pro/ENGINEER WildFire 4: teaching material. Vladimir State University named after Alexander Grigorievich and Nikolai Grigorievich Stoletovs. - 140 p.

6. (2017) The basics of programming - milling. Available: http://cnc-code.ru/basic- programming/osnovy-programmirovaniyatokarnaya-o/ (Accessed: 22.02.2017).

7. (2017) $400 \mathrm{~V}$ features of the machine. Available: http://mashinform.ru/frezernyestanki/other/400v.shtml (Accessed: 22.02.2017).

8. (2009) SINUMERIK 802D sl. Siemens AG. $722 \mathrm{p}$. 